Michał Kruszelnicki

\title{
(Nie) Chcieć być wszystkim. Stawrogin i najgłębsza otchłań Dostojewskiego
}

\begin{abstract}
Kruszelnicki Michał, (Nie) Chcieć być wszystkim. Stawrogin i najgłębsza otchłań Dostojewskiego [(Not) to want to be everything. Stavrogin and Dostoevsky's final abyss] „Przestrzenie Teorii" 24, Poznań 2015, Adam Mickiewicz University Press, pp. 195-218. ISBN 978-83232-2982-7. ISSN 1644-6763. DOI 10.14746/pt.2015.24.11.
\end{abstract}

This paper proposes a new interpretation of Nikolai Vsevolodowich Stavrogin - a relentlessly intriguing character in Fyodor Dostoyevsky's novel The Devils. This reading opposes the very influential line of interpretation employed in works of thinkers working within the current of Russian symbolism and "cultural renaissance" from the beginning of the 20th century. The author argues that this "religious" interpretive tradition contributes to one of the greatest misunderstandings concerning Dostoyevsky's work in that it oversimplifies its ambivalence and obscures one of Dostoyevsky's darkest insights into the human soul, initially revealed in Notes From the Underground and from that time on recurring in each of his major novels. In the first part of the article, several classic Russian interpretations of Stavrogin are examined in order to show their common tendency to morally judge Stavrogin from the Orthodox point of view, recognize his greatest sin in the lack of faith in God and for that reason see before him only the perspective of selfdisintegration and inevitable death. The author argues that "religious" interpretations do not explain the mystery of Stavrogin. What is more, they homogenize the complexity of his character and offer an all-to-easy solution to the vital philosophical problem which reiterates in Dostoyevsky's entire mature fiction and which finds its greatest artistic representation in Stavrogin himself.

Ja jestem jeden - a oni to wszyscy.

(Fiodor Dostojewski, Notatki z podziemia $)^{1}$

Wszystkość to główny wróg Dostojewskiego. Ta 'wszystkośćc', bez której istnienie wydaje się ludziom zupełnie nie do pomyślenia.

(Lew Szestow, Na szalach Hioba) ${ }^{2}$

Jesteś szczęśliwym człowiekiem. Żal mi Pana, Sir, że tak łatwo Panu być szczęśliwym. Trzeba bardzo nisko upaść, by uważać się za szczęśliwego!

(Charles Baudelaire, Lettre à Jules Janin $)^{3}$

${ }^{1}$ F. Dostojewski, Notatki z podziemia, Gracz, przeł. G. Karski, London 1992, s. 39.

${ }^{2}$ L. Szestow, Na szalach Hioba. Duchowe wędrówki, przeł. J. Chmielewski, Warszawa 2003, s. 45.

${ }^{3}$ Ch. Baudelaire, Oeuvres posthumes, Nouvelle édition augmentée, Paris 2014, s. 234. 
Będzie tu mowa o Mikołaju Stawroginie. O postaci, „której złożoność jest rzadka nawet jak na Dostojewskiego"4, o której nie sposób jednoznacznie stwierdzić, „czy przyciąga, czy odpycha” swojego twórcę, będąc „zawsze nazbyt bliska jego sercu”, w której Dostojewski był może nawet „romantycznie zakochany”, „zniewolony” przez nią i „uwiedziony”6. „Stawrogin - słabość, urzeczenie, grzech Dostojewskiego" - napisał Nikołaj Bierdiajew. „Innych wspiera jako przedstawicieli idei, Stawrogina zna jako zło i zagładę. A pomimo to kocha go i nikomu nie odda, nie odstąpi go żadnej moralnej wykładni, żadnemu religijnemu kazaniu"7.

Zadając pytanie o tajemnicę osobowości i śmierci Stawrogina, wkracza się w obszar problematyki, której dotyczy już ogromny dorobek interpretacyjny. Trudno jednak nie zgodzić się z opinią Doroty Jewdokimow, że moment uznania, iż o bohaterach Dostojewskiego powiedziano już wszystko, co możliwe, byłby równoznaczny z twierdzeniem, że: „literatura rosyjskiego pisarza jest martwa” i „nie ma nam już nic nowego do powiedzenia"8.

W moim tekście mam zamiar pokazać, że jest odwrotnie. Że, jak pisał Wiaczesław Iwanow: Dostojewski „wiecznie stoi przed nami, z badającym i nieodgadniętym spojrzeniem, sam będąc nieodgadnięty, ale odgadując nas - mroczny i przenikliwy przewodnik po labiryncie naszej duszy przewodnik i podglądacz" ci Stawrogina, która przeciwstawia się wpływowej tradycji egzegetycznej, zainaugurowanej pracami myślicieli związanych $\mathrm{z}$ rosyjskim symbolizmem i „renesansem kulturowym” początku XX wieku. Żywię głębokie przekonanie, iż owa „religijna” linia interpretacyjna, która niezwykle mocno oddziałała na kształt późniejszej recepcji Dostojewskiego na świecie, przyczynia się do jednego z największych nieporozumień dotyczących dzieła tego pisarza, jako że spłaszcza jego ambiwalencję oraz zaciemnia pewne mroczne odkrycie, jakiego Dostojewski dokonał o człowieku jeszcze w czasach pisania Notatek $z$ podziemia i jakiego nigdy nie był w stanie

${ }^{4}$ R. Pope, J. Turner, Toward Understanding Stavrogin, "Slavic Review” 1990, vol. 49, no. 4 , s. 544 .

5 Д. Мережковский, Л. Толстой и Достоевский, Москва 2000, s. 384.

${ }^{6}$ Н.А. Бердяев, ставрогин, „Русская мысль” 1914, nr V, s. 80-89; <http://www.vehi. net/berdyaev/stvrogin.html>, dostęp: 12.01.2015.

7 Tamże.

8 D. Jewdokimow, Człowiek przemieniony. Fiodor M. Dostojewski wobec tradycji Kościoła Wschodniego, Poznań 2009, s. 12.

9 В.И. Иванов, Достоевский и ролан-трагедия, „Русская Мысль” 1911, май-июнь, <http://www.vehi.net/dostoevsky/ivanov.html\#_ftn1>, dostęp: 12.01.2015. 
porzucić, niezależnie od tego, jak bardzo chciał uchodzić za głosiciela piękna „Bożego świata” i cudowności życia zgodnego z fundamentalnymi zasadami prawosławnej antropologii. Jeśli ignoruje się to odkrycie Dostojewskiego, jeśli próbuje się zamknąć uszy na jego ciągłą obecność w postawach i wypowiedziach jego czołowych bohaterów, to oswaja się i ugłaskuje twórcę, który, moim zdaniem, albo pobudza do wątpienia, podważa wszelkie oczywistości, szokuje i przeraża stawianiem „przeklętych problemów", albo przestaje fascynować, a jego dzieło staje się martwe.

W dalszym ciągu tekstu rekonstruuję kilka klasycznych rosyjskich interpretacji Stawrogina. Czynię to $\mathrm{w}$ celu wydobycia wspólnej im wszystkim tendencji do umieszczania tej postaci przed sądem chrześcijańskiej moralności, który uznając za największy grzech odstąpienie od Boga i zasady miłości bliźniego, skazuje Stawrogina na rozpad osobowości, „niebyt” i pewną śmierć. Po tej rekonstrukcji próbuję wykazać, że wykładnie te nie wyjaśniają tajemnicy głównego bohatera Biesów, a co więcej - dokonują rażącego ujednoznacznienia jego charakteru i oferują nazbyt proste rozwiązanie wielkiego filozoficznego problemu, jaki przewija się w całej dojrzałej twórczości autora Zbrodni $i$ kary i jakiego Stawrogin jest najwybitniejszą artystyczną reprezentacją. Analizie tego problemu poświęcona jest druga połowa artykułu.

\section{2.}

W ramach religijnych interpretacji przyjmuje się, że świat i życie ludzkie w dziele Dostojewskiego zorganizowane są zgodnie z hierarchicznym systemem wartości, na którego szczycie stoi Bóg oraz osoba ludzka, nosząca w sobie część Boskiego Obrazu. Osoba ludzka godna jest absolutnego szacunku i bezwarunkowej miłości. Ta miłość jest w stanie przezwyciężyć wszelkie zło i moralne upadki człowieka. Komentatorzy związani z tym nurtem recepcji wskazują „na niemożliwość życia człowieka pozbawionego wiary w Boga, klęskę świadomości pozbawionej religijnego odniesienia"10. $\mathrm{Na}$ ich prace o Dostojewskim pada cień wybitnego rosyjskiego filozofa i patrona symbolistów, Władimira Sołowjowa, który określił Dostojewskiego mianem „proroka prawdziwego chrześcijaństwa”. Zdaniem Sołowjowa, „poznawszy zło oraz wszystkie czarne strony ludzkiej egzystencji, [Dostojewski] przeciwstawiał mu nieskończoną potęgę miłości i we wszystkich utworach głosił jej zwycięstwo"11. Są jednak tacy

10 D. Jewdokimow, dz. cyt., s. 8.

11 W. Sołowjow, Trzy mowy ku czci Dostojewskiego, przeł. H. Paprocki, [w:] Okrutny talent. Dostojewski we wspomnieniach, krytyce $i$ dokumentach, wybór, wstęp i przypisy 
bohaterowie u Dostojewskiego, którzy nie są zdolni ani do miłości, ani do wiary, ani do zbudowania więzi z drugim człowiekiem. Na przykład i przede wszystkim - Stawrogin. „Od jednostki, która utraciła ową więź, wymaga się przede wszystkim wyrzeczenia się samotności i pychy, aby przez ten akt mogła się ona zjednoczyć z całym ludem" - poucza Sołowjow (tamże). To właśnie, zauważmy, proponuje Stawroginowi mnich Tichon. Stawrogin rzuca mu w twarz przekleństwo i zdecydowanym krokiem wychodzi z celi świątobliwego starca. O nie, Dostojewski na pewno nie we „wszystkich utworach” głosił „zwycięstwo miłości”, jak chciał Sołowjow...

Dla takich „odszczepieńców” jak Stawrogin czołowi rosyjscy glosatorzy projektują marny koniec. Również w ślad za Sołowjowem: W Biesach, pisze filozof, grupa bezbożnych rewolucjonistów i przestępców „ginie w haniebny sposób”, podczas gdy „zbawiona przez wiarę Rosja klęka przed Zbawicielem” (tamże). Wszyscy „potępieni” wynieśli swoje dumne Ja ponad drugiego człowieka i ponad Boga, zaburzyli naturalną hierarchię bytu i dlatego sami siebie wydali na łup wieczystego, nienasyconego pragnienia zastąpienia prawdziwego Absolutu jakąś ziemską namiastką. Dlatego muszą zginąć.

W pracy pt. Dostojewski $i$ jego chrześcijański światopoglad Mikołaj Łosski niedaleko odchodzi od ustaleń Sołowjowa:

Dla tego, kto utracił Boga i zagubił zdolność do indywidualnej miłości - powiada - cały system wartości rozpada się na oddzielne elementy i normalne stopnie wartości przestają dla człowieka istnieć. Człowiek, przeżywający taką katastrofę, znajduje się w sytuacji tym niebezpieczniejszej, im szczodrzej jest obdarowany duchowo i czym większą siłę posiada. W rzeczy samej, taki człowiek nieuchronnie wstępuje na drogę ryzykownych doświadczeń i fantastycznych przedsięwzięć ${ }^{12}$.

Dla Łosskiego sprawa jest prosta: odrzucenie Boga, najwyższego i najważniejszego punktu odniesienia, sprawia, że wszystkie idee i działania jednostki tracą sens, a duszę ludzką zaczyna drążyć pustka: „bez hierarchicznej jedności wartości cel życia traci określoność, a dusza staje się pusta" (tamże, s. 242). Łosski umieszcza Stawrogina pośród ludzkich cieni, dekadentów ogarniętych po zanegowaniu Boga apatią, depresją czy nudą (wszystkie te znaczenia zawiera łaciński termin acedia, jakim posługuje się komentator), nie omieszkując przypomnieć, że acedia jest „najstraszniejszym ze śmiertelnych grzechów” (s. 247). Dalej pisze:

Z. Podgórzec, Kraków 1984, s. 347, 340. Kolejne cytaty z tej pracy lokalizuję bezpośrednio w tekście.

12 Н.О. Лосский, Достоевский и его христианское мировоззрение, New York 1953, s. 237. Kolejne cytaty z tej pracy lokalizuję bezpośrednio w tekście. 
Depresja następuje wtedy, kiedy człowiek stojący na fałszywej drodze [...] traci miłość do osobowych i nieosobowych wartości; od tego momentu następuje utrata zdolności do emocjonalnego przeżywania wartości, utrata wszelkich celów życia i skrajne opustoszenie duszy. Oto śmiertelny grzech oddalenia od Boga, od wszelkich istot żywych i od wszelkiego dobra. Ów grzech zawiera też w sobie własną karę - niekończącą się tęsknotę odstąpienia od Boga. (s. 247)

$\mathrm{Na}$ sam akt samobójstwa Stawrogina Łosski patrzy z pryncypialną chrześcijańską... odrazą. Jego ostatnie słowa o bohaterze brzmią: „Zakończył życie, wieszając się, czyli tym wstrętnym sposobem, do jakiego uciekają się ludzie znajdujący się w rozpaczliwym przygnębieniu" (s. 249).

Wiaczesław Iwanow wpisuje świat powieściowy Biesów w mityczny schemat. Oto czysta i niewinna Ziemia Rosyjska, symbolizowana w powieści przez kulawą i jurodiwa Marię Liebadkiną, dręczona przez demony rywalizujące w niej z Chrystusem o władzę nad sumieniem rosyjskiego narodu, czeka na swojego oblubieńca, modli się o to, aby przybył godzien obrazu samego Boga, który nosi w sobie. Maria prędko dostrzega jednak w Stawroginie tylko udawanego księcia, zwykłego zabójcę, a nie „jasnego sokoła”. Stawrogin - wywodzi Iwanow - jest nosicielem demonicznych sił mroku i zła, narzędziem Szatana, który zaprzepaścił podarowaną mu „świątynię” i sprzeniewierzył się swojemu imieniu, ukutemu od greckiego słowa krzyż ( $\sigma \tau \alpha v \varsigma o ́ \varsigma)$, jak gdyby w celu zasugerowania, że w przeznaczeniu jego posiadacza leży jakiś wielki duchowy wyczyn.

Jemu w tajemniczy sposób zaproponowane zostało pewne królewskie namaszczenie. On - Iwan-carewicz; wszyscy, którzy się doń zbliżają, wypróbowują jego niezwykły, nieludzki urok. Na niego przelana została łaska mistycznego zrozumienia ostatecznych tajemnic o narodowej duszy i jej oczekiwaniach na Bogonosiciela $^{13}$.

Stawrogin nie tylko nie jest jednak w stanie wypełnić swojego wielkiego przeznaczenia, ale też nie umie odegrać szatańskiej roli Iwana łże-carewicza, na jaką liczy cyniczny manipulator Piotr Wierchowieński. Nie znajduje po temu wystarczającej siły woli: „Wszystkich i wszystko zawodzi on, i wiesza się, jak Judasz, nie dotarłszy do swojego demonicznego barłogu w ponurym górskim wąwozie" - z antypatią i niejaką złością konkluduje Iwanow (tamże).

Dramatyczne wyznanie Stawrogina: „Nigdy nikogo nie potrafię pokochać" orientuje Iwanowa wraz z wieloma komentatorami na inny ważny

13 В.И. Ива́нов, Достоевский и роман-трагедия, „Русская Мысль” 1911, май-июнь, $<$ http://www.vehi.net/dostoevsky/ivanov.html\#_ftn1>, dostęp: 12.01.2015. Kolejne cytaty z tej pracy lokalizuję bezpośrednio w tekście. 
dla interpretacji religijnych wątek. W teologii prawosławnej miłość postrzegana jest jako najważniejsza zasada poznania i uczucie umożliwiające twórczość. Gdy miłość przeobraża się w miłość własną, następuje tylko spadek mocy twórczej. Miłości własnej wtóruje pogarda dla drugiego człowieka, chęć wywyższania się ponad innych. W słynnym fragmencie swojego referatu Iwanow określa Stawrogina mianem „rosyjskiego Fausta”, ale „Fausta negatywnego, dlatego że wyczerpała się w nim miłość, a wraz z nią owo dążenie, które zbawia Fausta" (tamże).

Ten wątek będzie podkreślał później m.in. Siergiej Hessen: „Na tym właśnie polega jego droga krzyżowa, upamiętniona $\mathrm{w}$ jego imieniu (otausós): brakuje mu miłości, którą jest jedynym źródłem prawdziwej wiary, $\mathrm{i}$ on sam uświadamia sobie tę całkowita nieobecność miłości w sobie"14. Niezdolność do miłości bliźniego oznacza niezdolność do wiary w Boga, której, zdaniem Hessena, Stawrogin co prawda pragnie, ale tylko swoim „rozumem”, nie zaś „sercem”. Jego zguba nie bierze się ze zbrodni, jakich dokonał, lecz z niezdolności do wiary w Boga, którego nieskończona i bezwarunkowa miłość pozwala na zbawienie nawet największych grzeszników, byleby tylko potrafili oni zdobyć się na akt wiary w odkupieńczą siłę tej miłości. Brak takiej kompetencji pogrąża Stawrogina $\mathrm{w}$ alienacji, przygnębieniu i rozpaczy:

Świadomość niezrealizowanej miłości połączona z niezdolnością do kochania w tym piekło Stawrogina. Nie tylko swoim rozumem, ale całą swoją istotą nie wierzy on w Boga, od którego odstąpił, rozerwawszy związek miłości, poprzez który wszystkie istoty związane są z Bogiem i z sobą nawzajem. Uświadamiając sobie swoje odejście od Boga, on pokonuje granice swojej niewiary, jednak i to robi tylko rozumem, który zmusza go do pragnienia wiary i tym samym jeszcze ostrzejszego przeżywania swojej własnej niezdolności do kochania, a tym samym, do wiary. (tamże, s. 64)

Siergiej Bułgakow występuje z inną propozycją na temat Stawrogina, również osadzoną w dogmatyce chrześcijańskiej. W jego opinii Mikołaja Wsiewołodowicza tak naprawde „nie ma”, jest on pozbawiony rzeczywistości, niczym aktor, który oddaje siebie i swój umysł innym. W myśli tej słychać echa tradycji teologicznej, głoszącej nierealność i bezpłodność zła jako braku dobra. Stawrogin miałby być takim właśnie wcieleniem całkowicie biernego zła, „synem niebytu”.

To dlatego staje się on duchowym prowokatorem, rozpala innych tym, czym sam nie płonie i najwidoczniej nie potrafi zapłonąć. Stawrogin nie istnieje, ponieważ

14 С.И. Гессен, Трагедия зла (фблософбккий образ Ставрогина), „Путь” 1932, nr 36, s. 60, <http://www.odinblago.ru/path/36/3>, dostęp: 12.01.2015. Kolejne cytaty z tej pracy lokalizuję bezpośrednio w tekście. 
włada nim duch niebycia, i on sam wie, że go nie ma, stąd cała jego męka, cała dziwaczność jego upadku [...]; a także owa zagłada, jaką nieuchronnie i nieodwracalnie przynosi on istotom $\mathrm{z}$ nim związanym ${ }^{15}$.

Rosyjskie interpretacje lubią kontrastować postaci Kiriłłowa i Stawrogina z Biesów. Pozwala to lepiej ugruntować pogląd, że tylko ten, kto nie zerwał totalnie związku ze światem i drugim człowiekiem, a tym samym z Bogiem, ma szansę na normalne życie. Dlatego podkreśla się fakt, że Kiriłłow pali lampkę przed ikoną, bawi się z dzieckiem piłką, w przypływach szczerości mówi o swoim nieledwie dziecięcej miłości do świata i roztkliwia się nad wiosennymi listkami na drzewach. Z tych oznak S. Bułgakow wnioskuje, że:

Przy wszystkich jego wątpliwościach, w sercu Kiriłłowa goreje wiara w Chrystusa, chociaż nie potrafi wierzyć w niego jako Syna Bożego. Stawrogin - odwrotnie. On wie, gdzie leży zbawienie, ale jego wiara nie wynika z serca, dlatego nie wzrośnie z niej żaden duchowy owoc. (tamże)

Również Gieorgij Florowski mówi o Stawroginie jako „człowieku niebytu”, którego miotające nim biesy doprowadziły do przerażającej martwoty:

Najstraszniejsze jest opowiadanie [Dostojewskiego] wtedy, gdy z niezrównaną ostrością przedstawia on martwe bagno rozpadającego się ducha (мертвую зыбь распавшегося духа), spustoszenie upadłych ludzi, kiedy pokazuje on straszne obrazy niebytu. Taki jest Stawrogin ${ }^{16}$.

Zarówno Bułgakow, jak i Florowski wskazują, że Stawrogin, w przeciwieństwie do innych „biesów”, nie udręcza samego siebie swoimi ideami. One nękają i wzywają do ekstremalnych czynów innych (Szatowa, Kiriłłowa, Wierchowieńskiego). Stawrogin jako wcielenie zła pasożytniczo zaszczepia się na innych, ponieważ nie ma własnej mocy twórczej, może żyć tylko na cudzy rachunek. Podobnie jak Sołowjow, Florowski usilnie chce jednak widzieć w Dostojewskim wielkiego optymistę, który siłę do walki z owym złem czerpie z głębokiej prawosławnej wiary: „Ale i nad tym niebytem brzmi uroczysta i wszystko zwyciężająca Hosanna. W tej Hosannie tkwi największa tajemnica Dostojewskiego. W niej jego siła" (tamże).

15 C.Н. Булгаков, Русская трагедия, „Русская Мысль” 1914, Кн. IV, s. 1-26; $<$ http://www.vehi.net/bulgakov/tragediya.html>, dostęp: 12.01.2015. Kolejne cytaty z tej pracy lokalizuję bezpośrednio $\mathrm{w}$ tekście.

16 Г.В. Флоровский, Религиозные темь Достоевского, [w:] tegoż, О Достоевскол, Москва 1990, s. 390. 


\section{Wątek „nieistnienia” Stawrogina podejmie Fiodor Stiepun.}

Tak naprawdę Stawrogina w powieści nie ma: jest on w niej obecny jako dopiero co zaszłe za horyzont słońce. O tym, czym Stawrogin był do swojego pojawienia się w powieści, czytelnik może tylko niejasno domyślać się po tej złożonej walce idei i uczuć, którymi gdzieś za granicą potrafił on zatruć dusze swoich później odwracających się od niego przyjaciół i wyznawców ${ }^{17}$.

Po chwili Stiepun odsłania dobrze nam już znane karty. Klucz do tajemnicy Stawrogina, osądza, tkwi

w całkowitej stracie swojej osobowości, owego schronienia dla Bożego podobieństwa człowieka. O tej stracie świadczą zarówno przyznanie się Stawrogina, że wierzy on w diabła, odwiecznie zafrasowanego zrywaniem związku między człowiekiem a Bogiem, jak i całe jego prowokatorskie działanie, albo, może dokładniej - jego prowokująca bezskuteczność. (tamże)

Wśród rosyjskich interpretacji religijnych znajdują się też takie, które akcentują niezdecydowanie Stawrogina, jego „letniość”, ponownie jednak odnajdując jej powód w... ateizmie bohatera. Zdaniem Dymitra Mereżkowskiego, Stawrogin nie wie, czego chce, i stąd jego klęska. Pozornie oskarżając siebie, a w istocie usprawiedliwiając, odwraca porządek rzeczy, twierdząc, że w świecie nie ma nic wartego bezwzględnej wiary i życzeń, więc dlatego niczego nie pragnie totalnie. Ale w rzeczywistości jest odwrotnie: $\mathrm{z}$ tego, że jego chcenie jest letnie, nie wynika wcale, że w świecie nie ma nic wartego zachodu:

Oto tajny bieg jego myśli: siła moja jest bezgraniczna i gdyby w świecie byłoby warto czegoś pragnąć, to ja bym pragnął w sposób nieograniczony; ale ponieważ wola moja jest apatyczna, bezsilna, to znaczy, że w świecie w ogóle nie ma przedmiotu godnego bezgranicznych życzeń. [...] On ginie nie dlatego, że szuka czegoś niewłaściwego i nie dlatego, że nie można w ogóle znaleźć tego, czego on szuka, lecz ponieważ on sam nie uświadamia sobie, czego pragnie ${ }^{18}$.

Znów nie trzeba się domyślać, że również dla Mereżkowskiego ową rzeczą wartą bezgranicznych życzeń jest Bóg. To jego Stawrogin „szuka”, ale do samego końca nie jest tego świadomy, brakuje mu siły do opowiedzenia się nawet po stronie ekstremalnego zła, co być może pozwoliłoby mu uświadomić sobie i przyjąć ocalającą siłę wiary. W jednym z kluczowych fragmentów swojego dyskursu Mereżkowski poświęca szczególną

17 Ф.А. Степун, «Бесь» и большевистская революиия, [w:] Русское зарубежье в год тысячелетия крещения Руси, Москва 1991, s. 365-376, <http://www.vehi.net/dostoevsky/ stepun.html>, dostęp: 12.01.2015.

18 Д. Мережковский, Л. Толстой и Достоевский, Москва 2000, s. 382. Kolejne cytaty z tej pracy lokalizuję bezpośrednio w tekście z oznaczeniem M i podaniem numeru strony. 
uwage tajemniczej uwadze wypowiedzianej przez Stawrogina: „Na świecie nic się nie kończy" (На свете ничего не кончается). To niezwykłe zdanie, które już niedługo okaże się jednym z kluczy do naszej interpretacji zagadki Stawrogina, dla Mereżkowskiego dowodzi jedynie „błędu”, jaki popełnia bohater, nie wierząc w Boga, który jest przecież ostatecznym celem ludzkich dążeń:

Oto główny błąd, z którego powodu on ginie: nie na świecie w ogóle, a tylko w nim, w jego świadomości rzeczywiście 'nic się nie kończy'. Kraniec wszystkiego w świadomości ludzkiej jest Bogiem; ale świadomość Stawrogina nie chce swojego końca, nie chce Boga. (M, 382)

Przegląd klasycznych rosyjskich interpretacji Stawrogina kończymy na stanowisku Nikołaja Bierdiajewa. Bierdiajew również podkreśla niezdecydowanie Mikołaja Wsiewołodowicza, ale przypisuje je nieskończonym i bezkresnym ambicjom jego twórczego, „genialnego" ducha. Stawrogin jest rozdarty między dobrem a złem, Bogiem i Szatanem, pragnieniem życia i śmierci:

On szuka ostateczności, bezmierności, zarówno w dobru, jak i złu. Tylko tego, co boskie, jemu wydaje się za mało, we wszystkim musiał przekroczyć krańce i granice ku ciemności, złu, diabelskości. Nie mógł i nie chciał dokonać wyboru między Chrystusem a Antychrystem, Bogoczłowiekiem i Człowiekiem-Bogiem. Zatwierdzał i jednego, i drugiego, pragnął wszystkiego, wszelkiego dobra i wszelkiego zła, pragnął tego, co bezmierne, bezkresne, bezgraniczne ${ }^{19}$.

Klasyczni rosyjscy komentatorzy albo potępiają moralnie Stawrogina, określając go mianem „syna niebytu” i wcieleniem szatańskiej pychy, albo znajdują sposób na jego „zbawienie”. Bierdiajew reprezentuje tę drugą opcję, odczytując samobójczą śmierć bohatera jako gest potwierdzający przed Bogiem jego wyrzuty sumienia i „skruchę” za popełnione zło, ukazujący jego „wielkoduszność”. Stawrogin „żałuje” popełnionych grzechów i chociaż z początku „boi się” samobójstwa jako aktu „wielkoduszności” (Ставрогин боялся салоубийства, боялся показать великодушие), to jednak ostatecznie dokonuje tego zbożnego aktu. Dla prawosławnego serca Bierdiajewa nie do przyjęcia jest totalna zagłada Stawrogina; ono zawsze żywi nadzieję, że jeśli nie zaznał on łaski w tym życiu, to na pewno zazna jej po śmierci, odrodzi się w zaświatach i też będzie zbawiony: „Ale nastanie mesjanistyczna uczta, do którą zostanie powołany i Stawrogin, i tam zaspokoi on swój bezmierny głód i bezmierne swoje pragnienie" (tamże). Bierdiajew wyraźnie ubolewa nad tym, że Stawrogin niczego nie dokonał, chociaż predysponowany był do osiągnięcia wszystkiego, czego by zechciał. Jego los odzwierciedla metafizyczny

${ }^{19}$ Н.А. Бердяев, dz. cyt. Kolejne cytaty z tej pracy lokalizuję bezpośrednio w tekście. 
dramat jednostki o nadmiernych, przekraczających możliwości człowieka pragnieniach i apetytach: „To światowa tragedia wycieńczenia od bezmiaru, tragedia zdrętwienia i zagłady ludzkiej indywidualności od śmiałości na bezmierne, nieskończone dążenia, nie znające granicy, wyboru i oprawy” (tamże). Rzecz jasna, ostateczną „oprawą” i „granicą” ludzkich dążeń jest dla Bierdiajewa Bóg. Rozstrzygający wniosek myśliciela jednocześnie mieści się w konwencji typowej dla tradycji, z jakiej ten się wywodzi, oraz wskazuje na wątek kluczowy dla jego własnej filozofii. Stawrogin ginie, bo jego siła twórcza nie była ugruntowana $\mathrm{w}$ religijnej wierze. Tylko wiara objawia bowiem sens twórczości, a negacja Boga prowadzi do impotencji i braku tworzenia. Twórczość pozbawiona fundamentu religijnego wygasa i zamiera, co pokazują na swoim przykładzie tak Stawrogin, jak i... Nietzsche, którego Bierdiajew nie omieszkał wciągnąć do swojego równania: „Droga do objawienia twórczości człowieka biegnie przez śmierć Stawrogina, przez zagładę Nietzschego" (tamże).

\section{3.}

Większość kluczowych wątków z przedstawianych wyżej interpretacji Stawrogina odżywa $\mathrm{w}$ tekście wybitnego polskiego badacza literatury rosyjskiej - Ryszarda Przybylskiego. Opierając swoją spektakularną i wpływową lekturę przede wszystkim na dogłębnej znajomości właśnie tej, religijnej tradycji interpretacyjnej, Przybylski proponuje, jak się zdaje, dwie wzajemnie wykluczające się wykładnie, które z czasem jednak objawiają swoją światopoglądową proweniencję, a tym samym - komplementarność. $\mathrm{Z}$ jednej strony badacz prezentuje Stawrogina jako znudzonego, niezdecydowanego paniczyka (,Stawrogin nie jest ani gorący, ani zimny. Jest letni”)20, szukającego mocnych wrażeń, który jednak ostatecznie macha na wszystko ręką "trochę zblazowanego, pubertalnego kontestatora" (tamże, s. 42), z drugiej zaś konstruuje jego obraz jako nietzscheańskiego nihilisty, który po skonstatowaniu „śmierci Boga” wkracza na drogę wyniszczającego jego osobowość sceptycyzmu i relatywizmu w stosunku do świata wartości. Dopóki Stawrogin wierzył - a wiemy z powieści, że w czasie pobytu za granicą był człowiekiem głęboko wierzącym i gdyby „ktoś mu udowodnił że prawda jest poza Chrystusem, to wolałaby zostać z Chrystusem niż z prawdą" - to idee, które głosił m.in. Szatowowi, Kiriłłowowi czy Wierchowieńskiemu, wydawały się absolutne i niewzruszone. Dla Stawrogina-nihilisty i ateisty są już tylko ruchome,

${ }^{20}$ R. Przybylski, Stawrogin, [w:] M. Janion, R. Przybylski, Sprawa Stawrogina, posłowie T. Komendant, Warszawa 1996, s. 37. Kolejne cytaty z tej pracy lokalizuję bezpośrednio w tekście. 
względne i kłamliwe, jak każda rzecz wymyślona przez człowieka. Ten krok od bezwzględnej wiary do nihilizmu i ateizmu okazuje się jednak krokiem samobójczym. Bo dla tego, kto odrzucił Boga, nie ma już odwrotu. Rozpoczyna się bowiem morderczy ruch usuwania kolejnych podstaw, wartości i ideałów, który skończyć się może tylko dyssatysfakcją, obłędem i śmiercią. Przybylski pisze: „ateista nie może być wierny jednej ideologii, chyba... chyba że wpadnie w rodzaj ideologicznej bigoterii i uwierzy w światopogląd, jak w Boga. Stawrogin nie mógł uwierzyć w żadną ideę" (tamże, s. 37). Obie diagnozy Przybylskiego - Stawrogin jako niezdecydowany puberylistyczny abnegat oraz Stawrogin - nihilista, relatywista i sceptyk - mają wspólny mianownik w postaci... jego niewiary. W pierwszym przypadku nie pozwala ona nadać kierunku nawet jego negacjom i transgresjom, co skazuje go na potworną nudę i depresję, w drugim zaś odcina go od doświadczenia autentycznej pełni i najgłębszego sensu życia, prowadząc do duchowej ruiny jego osobowości: „Skończył go ostatni z siedmiu grzechów głównych: unynije - smutek, przygnębienie, nuda" (tamże s. 38) - mówi Przybylski, a w twierdzeniu tym nietrudno dosłyszeć inspirację fragmentami pracy M. Łosskiego, który jako pierwszy pisał o smutku czy przygnębieniu jako „najstraszniejszym ze śmiertelnych grzechów". Przybylski nie tylko gotów jest rzucić ateistów w otchłań bezpłodnych ludzkich cieni, których wszelka aktywność a priori podgryzana jest przez rzekomo koniecznie związany $\mathrm{z}$ ateizmem relatywizm, lecz także nie widzi przed nimi szansy na życie. Dla polskiego uczonego wiara w Boga jest warunkiem samego ż y c i a, w czym też zgadza się on z fundamentalnym przekonaniem klasycznych egzegetów rosyjskich. „Żyć oznacza wierzyć" - twierdzi (tamże). Według Przybylskiego, wybierając ateizm, Stawrogin wybiera śmierć:

Odrzucając Chrystusa, odrzucił idealne ja człowieka i tym samym - ponieważ osobę konstytuuje nieustanny dialog ze swoim idealnym ja - przekreślił siebie jako indywidualność. Żaden światopogląd nie jest w stanie dostarczyć mu idealnego wzoru osobowości, ponieważ idea, która nie jest wiarą, przepływa przez jego duszę, pozostawiając po sobie gorycz pustki. Tylko wiara może zatrzymać ideę w człowieku i uczynić z niego osobę. Niewiara rozkłada Ego. [...] Duszę Stawrogina przemielił młyn nowożytnych poglądów na proch. Stawrogin zniszczył dom swojej duszy. Spalił próg osoby. Został sam ze swoją pustką. (tamże, s. 40)

\section{4.}

Religijne interpretacje „zagadki Stawrogina” wydają mi się strasznie podejrzane właśnie dlatego, że tak ładnie wszystko się w nich układa i do siebie pasuje. Brak wiary = transgresja, melancholia, poczucie bezsensu 
i niechybne samobójstwo... Co w takim razie z dictum samego Bierdiajewa z początku naszego tekstu, że Dostojewski nie chciał oddać Stawrogina „żadnej moralnej wykładni, żadnemu religijnemu kazaniu”...? Myślę, że najwyższy czas poszukać odpowiedzi na pytania, na jakie interpretacje te $\mathrm{n}$ ie udzielają odpowiedzi. Dlaczego Stawrogin nie jest w stanie wierzyć w Boga? Skąd bierze się jego niezdolność do obrania jakiejś konkretnej drogi, czy to w kierunku dobra... W kierunku zła? Czy rzeczywiście brak wiary jest tym jedynym i ostatecznym czynnikiem, który skazuje pupila Dostojewskiego na rozpad osobowości, a w końcu na „haniebną” i „wstrętną" śmierć (Sołowjow, Łosski)? I wreszcie: czy sam Dostojewski, który całe życie męczył się ze swoimi własnymi wątpliwościami religijnymi, mógłby tak kategorycznie potępić swojego najbardziej fascynującego bohatera za... zwątpienie i niewiarę?

A oto ciekawe skądinąd zjawisko. Sami myśliciele rosyjscy, którzy tak chętnie potępiają „bezbożnego” Stawrogina, nader często zdradzają się z wątpliwościami, czy ich interpretacje rzeczywiście prowadzą do ostatecznego rozwiązania zagadki tej postaci... Tak jakby byli świadomi niewystarczalności własnych propozycji, jakby przeczuwali, że w Stawroginie jest coś „więcej”, niż powiedzieli, czy w ogóle da się powiedzieć. „W Biesach nie podano bezpośredniego i jasnego rozwiązania tajemnicy Stawrogina” - przyznaje Bierdiajew ${ }^{21}$. „Zagadnienie miejsca, które główny bohater Biesów zajmuje w metafizycznym planie powieści, pozostaje dotychczas nierozwiązane, a opublikowana niedawno Spowiedź Stawrogina jeszcze bardziej zaostrzyła spór o ideologiczną wymowę tego zagadkowego bohatera Dostojewskiego" - mówi Hessen ${ }^{22}$.

I wreszcie, głos dla nas najważniejszy: kapitalny wgląd Mereżkowskiego, który chyba nie wiedział nawet, do jakiego stopnia miał rację, gdy pisał: „Wydaje się czasem, że Dostojewski nie chce, albo nie waży się powiedzieć o Stawroginie czegoś właśnie najważniejszego" (M, 382). No właśnie, tak naprawdę nie znamy decydujących dla rozwiązania zagadki ostatnich godzin życia Stawrogina, biegu jego myśli i uczuć, który poprowadził go od konstatowania niemożliwości samobójstwa, do jego konieczności. Czy mógł się zabić ktoś tak wybitny, ktoś o tak potężnej osobowości? Czy człowiek, który jeszcze niedawno wychodził z celi ojca Tichona $\mathrm{z}$ przekleństwem na ustach, pozostawiając za sobą przerażonego jego determinacją starca, mógł podjąć taką decyzję, właściwą (na ogół) ludziom słabym? I to z jakiego powodu? Ateizmu? I oto zgłaszający podobne wątpliwości Mereżkowski, na długo przed Bachtinem, wypowiada następujące, niesłychane w kontekście aury religijnego ożywienia, w jakiej

${ }^{21}$ Н.А. Бердяев, Ставрогин...

${ }^{22}$ С.И. Гессен, dz. cyt., s. 49. 
pisał swoją pracę, słowa: „Śmierć Stawrogina jest takim samym sztucznym, przylepionym z zewnątrz, konwencjonalnym (условныци) końcem, jak chrześcijańskie 'zmartwychwstanie' Raskolnikowa” (M, 383-384).

Co tu się stało? O czym mówi Mereżkowski? Czy Stawrogin wcale nie musiał popełniać samobójstwa? Czy Dostojewski widział przed nim jednak przyszłość, lecz z jakichś powodów zdecydował, że lepiej Stawrogina raz i na zawsze usunąć ze świata? Posłuchajmy samego Mereżkowskiego:

Czy to samobójstwo nie było przypadkiem koniecznością nie tyle dla Stawrogina, co dla twórcy Biesów, dla samego Dostojewskiego? [...] Jak gdyby doprowadził on swojego bohatera do pewnej granicy, do której sam doszedł i chociaż czuł, że na tej granicy zatrzymać się nie można, że Stawrogin powinien pójść dalej, mimo wszystko porzucił go, nie poszedł za nim, ponieważ pójście dalej samemu Dostojewskiemu wydawało się zbyt straszne. (M, 384)

Intuicje Mereżkowskiego są kapitalne i tym bardziej inspirujące, że rosyjski krytyk nie daje ze swej strony żadnej odpowiedzi. My jednak zapytajmy: dokąd Dostojewski bał się pójść? Dokąd zmierzał Stawrogin i co takiego odkrył tam razem z nim autor Biesów, że przeraził się własnego odkrycia i musiał zakończyć sagę Stawrogina, zabić go, byleby tylko nie objawić światu (i sobie!) tego, co znajduje się po drugiej stronie "granicy"?

Oto nasz problem.

\section{5.}

Czy tą otchłanią, którą Stawrogin pozwolił dostrzec Dostojewskiemu, był problem europejskiego nihilizmu, poczucia braku sensu w pozbawionym boskiej kurateli świecie, który stacza się od teraz „w stronę niewiadomego X" (Nietzsche)? W przeciwieństwie do Przybylskiego Maria Janion, której ateistyczno-gnostycki światopogląd jest dobrze znany, widzi $\mathrm{w}$ ateizmie/nihilizmie Stawrogina oraz wypływającym z nich dramacie egzystencjalnym cechy świadczące o tragicznej wzniosłości tej postaci. Stawrogin według Janion to romantyczny buntownik i bojownik o wolność metafizyczną, pod której ciężarem jednak tragicznie się załamuje. Jest on postacią tragiczną, bo pomimo gigantycznego poznania, jakie osiągnął, „nie może wybrać”. Wszystkie wartości straciły dlań znaczenie, utracił wszelkie cele: „W Stawroginie ujawnia się nowa i nowożytna jakość tragizmu. [...] Porzuciwszy Boga, ugina się samotnie pod ciężarem wolności dobra i zła" 23 .

${ }^{23}$ M. Janion, Czy Stawrogin jest postacia tragiczna?, [w:] M. Janion, R. Przybylski, dz. cyt., s. 69 . 
W opinii Janion Stawrogin wpisuje się $\mathrm{w}$ obraz nihilisty zgodny z wywodami Nietzschego. Ale Dostojewskiego chyba nie przerażał nihilizm jako filozoficzny światopogląd, który konstatując śmierć Boga, skazuje jednostkę na zaklęty krąg wątpienia w kolejne figury wyższego „sensu". W słynnym liście do Natalii Fonwizinej jeszcze w 1856 roku pisarz sam siebie określał jako nieodrodnego syna nihilistycznej epoki: ,jestem dziecięciem wieku, dziecięciem niewiary i zwątpienia po dziś dzień, a nawet (wiem o tym) do grobowej deski"24. Taki człowiek nie mógł przeznaczyć Stawrogina na śmierć z powodu niewiary w Boga albo dlatego, że ten chciałby w Niego wierzyć, ale nie jest w stanie. Równie dobrze autor Zbrodni $i$ kary mógłby wtedy sam powiesić się na suchej gałęzi! Zarazem jednak Dostojewski był głęboko przekonany, że niesamowita idea, którą sam opisywał pod mianem „Człowieka-boga”, a którą niemal symultanicznie programował jako lekarstwo dla pogrążającej się w nihilizmie ludzkości F. Nietzsche - czyli suwerenne fundowanie nowych wartości i celów na gruzach starego, metafizycznie uporządkowanego świata - nie jest do zrealizowania dla człowieka. I nie przestawał wołać do swoich bohaterów: „sprawdzam!” i karać ich za marzenie o byciu człowiekiem-bogiem i nowym prawodawcą świata. Los Raskolnikowa, Kiriłłowa, Iwana Karamazowa dowodzi tego, że „stare wartości” nie dają się łatwo zakwestionować, a ci, którzy próbują tego dokonać, mogą albo skonstatować swoją pychę i pokajać się, albo oszaleć...

Stawrogin jest jednak inny. On ani nie przyznaje się do grzechu („Piszę o tym, aby udowodnić, że wobec wszystkich moich wspomnień byłem obojętny i w pełni nad nimi panowałem. Wszystkie razem w swej wielości odrzucałem i posłusznie znikały za każdym razem, gdy tego zapragnąłem”25), ani nie wariuje. Ostatni dokument, jaki po nim został - list pisany do Daszy - świadczy, że najspokojniej w świecie planował sobie nowe życie w odległym kantonie Uri, dokąd i ją zapraszał. Pamiętamy niezwykłą sugestię Mereżkowskiego: samobójstwo Stawrogina było koniecznością... ale dla Dostojewskiego, nie da Stawrogina! Przeciwnie do ujęcia Przybylskiego, a także Marii Janion, twierdzimy, że tak jak dla Stawrogina problemem nie jest brak wiary w Boga, tak, konsekwentnie, problemem nie jest dlań brak metafizycznie ugruntowanych celów i wartości. Jego niezdolność czy niechęć do wyboru jakiegoś normatywnego scenariusza życia nie musi wcale wynikać z nihilizmu, który rodzi podmywający normatywne podstawy życia i kultury relatywizm i scep-

${ }^{24}$ List F. Dostojewskiego do Natalii Fonwizinej z 20.02.1856, [w:] F. Dostojewski, Listy, przeł. Z. Podgórzec, R. Przybylski, Warszawa 1979, s. 115.

${ }^{25}$ F. Dostojewski, Biesy, przeł. T. Zagórski, Z. Podgórzec, London 1992, s. 646. Dalsze cytaty z tej powieści oznaczane są bezpośrednio w tekście jako B wraz z numerem strony. 
tycyzm. Chyba nieco na siłę próbuje się uczynić ze Stawrogina nihilistę opłakującego utratę sensu, dosłownie jakby Dostojewski był pisarzem przejętym roztrząsaniem filozoficznych problemów, a nie ludzkiego ducha.

Gdzie indziej trzeba więc szukać źródeł decyzji Dostojewskiego o uśmierceniu Stawrogina. Moim zdaniem, trzeba dokładniej przyjrzeć się temu, co odkrył on w czasie pisania Notatek $z$ podziemia, a co powracało doń nieustannie, wraz z każdą kolejną kreacją życiowego wykolejeńca czy nieszczęśliwego ateistycznego rezonera. A nie było to radosne odkrycie.

\section{6.}

W czasie 4-letniej syberyjskiej katorgi Dostojewski bezustannie marzył o „nowym życiu”, jakie będzie prowadził po powrocie, życiu wypełnionym humanistycznymi i religijnymi ideałami. Wyobrażał sobie (i często później o tym pisał), że ten, kto doświadczył więzienia (a tym bardziej, gdy spojrzał śmierci w oczy - jak on), po otrzymaniu „drugiej szansy” będzie radował się i wykorzystywał każdą minutę spędzoną na świecie. Po powrocie z katorgi dowiedział się o samym sobie czegoś zgoła innego. Lew Szestow powie, że ten, kto zetknął się z Aniołem Śmierci i otrzymał od niego „drugi wzrok”, nie może już zamknąć oczu i udawać, że nie widzi wi ęcej od innych... ${ }^{26}$. Dostojewski nie mógł nie dostrzec, że to „nowe życie”, które wreszcie można by „idealnie” prowadzić, dusi nie mniej niż więzienne mury:

ideały - te ideały, którymi koił swoją wycieńczoną duszę w dniach, kiedy jako zbrodniarz żył między najgorszymi ludźmi i dzielił z nimi ich los, te ideały nie uwznioślają, nie wyzwalają, lecz krępują i poniżają jak więzienne kajdany. Niebo dławi, ideały krępują, a całe ludzkie życie, tak jak życie mieszkańców martwego domu, przeobraża się w ciężki, męczący sen, w niekończący się koszmar... (Sz, 36-37)

Stąd właśnie, z tego doświadczenia, wywodzą się wszystkie ,jednostki przeklęte" w powieściach Dostojewskiego, które w miejsce pięknie, mądrze i moralnie przeżywanego życia wybierają to, co M. Łosski, a za nim R. Przybylski, z okropną moralizatorską tendencją, określają mianem „najstraszniejszego z grzechów śmiertelnych”: acedię - smutek i przygnębienie. Tymczasem Bierdiajew celnie zauważa, że najbardziej

26 Por. L. Szestow, Na szalach Hioba. Duchowe wędrówki, przeł. J. Chmielewski, Warszawa 2003, s. 33. Kolejne cytaty z tej pracy lokalizuję bezpośrednio w tekście z oznaczeniem $\mathbf{S z}$ i podaniem numeru strony. 
przejmujący bohaterowie Dostojewskiego tak naprawdę nic nie „robią”. Nic nie tworzą, nie budują w życiu - zajęci są tylko i wyłącznie „roztrząsaniem tajemnicy ludzkiego losu”27. Szestow dodaje, że „nie umieją [oni], i jak gdyby nie chcą, działać, tworzyć; wszędzie, gdzie się pojawiają, idzie za nimi zniszczenie i zagłada; prawdopodobnie po to, żeby nie dawać czytelnikowi chociażby iluzji 'końca' (Sz, 82). Człowiek z podziemia jako pierwszy u Dostojewskiego stwierdzi, że nie chce nikim się „stać”, ani „najnędzniejszym robakiem”, ani nawet „leniem”. „Kimś” - powiada stają się jedynie głupcy"28. On sam nie wie, czego chce, ale wie zarazem, że gdyby wiedział, to pozostawałoby mu już tylko... przestać istnieć. Cały sens swojej egzystencji czerpie ze świadomości, że nie jest taki jak inni, i dobrze pojmował istotę Notatek Leonid Grossman, gdy pisał, że to właśnie w nich ogłoszona została „bezgraniczna wolność ludzkiego chcenia, prawomocność jego namiętności do zniszczenia i chaosu, nienaruszalność wszystkich zachcianek i destrukcyjnych kaprysów indywidualnej samowoli”29.

W Notatkach $z$ podziemia Dostojewski odkrywa zatrważający paradoks, że człowiek nie chce szczęścia, woli niespełnienie zamiast spełnienia. Dlaczego? Chyba tylko po to, by przed samym sobą dowieść swojej wyjątkowości i strasznej egzystencjalnej wolności. Dla większości ludzi, niemal dla wszystkich, ta wolność jest największym ciężarem. Chcą się go prędko pozbyć, najlepiej kładąc sobie na grzbiet ciężar jakichś życiowych obowiązków, misji i celów. "Powinieneś” - zwie się ten wielki smok” - mawiał Nietzsche ${ }^{30}$. Przede wszystkim „powinniśmy” nadać swojemu życiu - na przykład dzięki pracy, rodzinie, osiąganiu kolejnych celów, no i oczywiście wierze w Boga - jakiś sensowny „kształt”. Są jednak tacy i to takie jednostki, jak się zdaje, Dostojewski ukochał najbardziej - którzy czują, iż „koniec”, zamknięcie, ugrzęźnięcie w jakimś konwencjonalnym scenariuszu życia są bardziej poniżające dla ich duszy niż cierpienie i niezaspokojenie. „Dwa razy dwa to już nie jest życie, proszę państwa, lecz początek śmierci”. „Człowiek zawsze owego dwa razy dwa jakoś się lękał” - powtarza Człowiek z podziemia ${ }^{31}$.

27 Н.А. Бердяев, Откровение о человеке в творчестве Достоевского, „Русская Мысль”1918, Кн. III-IV, <http://www.vehi.net/berdyaev/otkrov.html\#_ftnref2>, dostęp: 12.01.2015.

${ }^{28}$ F. Dostojewski, Notatki z podziemia..., s. 9.

29 Л. Гроссман, Достоевский, Москва 1963, <http://az.lib.ru/d/dostoewskij_f_m/text _0770.shtml>, dostęp: 12.01.2015.

${ }^{30}$ F. Nietzsche, To rzekt Zaratustra, przeł. S. Lisiecka, Z. Jaskuła, Warszawa 1999, s. 30 .

${ }^{31}$ F. Dostojewski, Notatki z podziemia..., s. 31. 
Jeżeli chcecie 'zrozumieć’ Dostojewskiego - radzi Szestow - powinniście nieprzerwanie powtarzać jego 'podstawową tezę': dwa razy dwa cztery jest początkiem śmierci. Należy wybierać: albo obalimy dwa razy dwa cztery, albo uznamy, że ostatnie słowo, ostatni sąd nad życiem należy do śmierci. Stąd nienawiść Dostojewskiego do szczęścia, równowagi, zadowolenia i jego fantastyczny paradoks: człowiek lubi cierpienie. $(\mathrm{Sz}, 66)$

Tę „nienawiść do szczęścia” widać w kolejnych wybitnych kreacjach literackich pisarza, w każdej powieści. W Zbrodni $i$ karze totalnie „bezproduktywnym” charakterem jest Swidrygajłow („Właściwie niczym się specjalnie nie interesuję, słowo daję [...]. Zwłaszcza teraz niczym się nie zajmuję..."). Z udawanym żalem wyznaje Raskolnikowowi, że nic w życiu nie „osiągnął”: „Ach, wie pan, żebym miał jakiekolwiek zajęcie, gdybym był ziemianinem, ojcem, ułanem, fotografem, dziennikarzem... Nic, żadnej specjalności! Czasami to jest bardzo nudne!"32. Wzruszający Kiriłłow z Biesów, który obmyśla plan samobójstwa, by dowieść boskości człowieka, a zarazem nieobecności dawnego Boga (Bóg jest dla niego bogiem strachu przed śmiercią), również nic nie „robi”. Nocami pije herbatę i chodzi po pokoju, a o świcie kładzie się spać („Lubię pić herbatę w nocy. Chodzę po pokoju i piję, do świtu. Za granicą to nie przyjęte" - B, 106). Żadna aktywność nie towarzyszy też umierającemu na gruźlicę i bezsilnie przeklinającemu okrutną Naturę Hipolitowi Tierientiewowi w Idiocie oraz mrocznemu Smierdiakowowi w Braciach Karamazow, nad którego rzekomym „upadkiem” pastwią się różni komentatorzy, pokazując, jak dosłownie „blaknie” on i znika od ciężaru dokonanej „zbrodni”. Zrozpaczony kapitan Sniegirow z kart tej samej powieści, apatycznie spędzający swoje dni w obskurnym pokoiku z 5-osobową rodziną, w skrajnej biedzie, $\mathrm{w}$ akcie niesamowitej dumy odrzuca finansową pomoc Katarzyny Iwanowny i Aloszy Karamazowa, a tym samym jedyną szansę na uratowanie życia choremu synkowi Iluszy i żonie. Pijak Marmieładow ze Zbrodni $i$ kary dzień i noc przesiaduje w brudnej i cuchnącej spelunie, podczas gdy jego córka Sonia pracą ulicznicy zarabia pieniądze, by jego rodzina miała co jeść. W momencie, gdy na horyzoncie migoce obietnica „nowego życia”, Marmieładow wykrada pieniądze zaoszczędzone dzięki cudem otrzymanej ponownie posadzie i znowu ląduje w najgorszym bagnie. Raskolnikowowi powie, że: „pragnie nie uciech, lecz bólu i łez!”33. Co łączy tych bohaterów? To, że nic nie jest im bardziej obce od perspektywy spełnienia, szczęścia i normalności. Wolą cierpienie, poniżenie i rozpacz... od szczęścia.

32 Tenże, Zbrodnia i kara, przeł. J.P. Zajączkowski, Warszawa 2002, s. 280, 447.

${ }_{33}$ Tamże, s. 34. 
Wreszcie - Stawrogin. Wszyscy oczekują od niego działania, „czynu”, a różni komentatorzy, zwłaszcza ci, którzy z bezpiecznej przystani swojej głębokiej wiary w Boga chętnie wyśpiewują hymny na cześć cudowności życia, zastanawiają się, dlaczego niczego nie „dokonał”. Jego impotencję przypisują „ateizmowi”. Lecz Stawroginem kieruje po prostu ten sam, paradoksalny lęk przed „spełnieniem”, jaki charakteryzuje wcześniej wymienione postaci, przy czym w jego przypadku Dostojewski dokonał arcydzieła literackiego kamuflażu, najpierw projektując dla niego wielką przyszłość (to jemu z tajemniczych przyczyn powierzył zaszczyt głoszenia swojej najgłębszej i ukochanej idei rosyjskiego narodu jako Bogonosiciela), by potem objawić jego konfundującą pokolenia czytelników twórczą niemoc. W broszurze wręczonej Tichonowi Stawrogin wyznaje, że mógłby w każdej chwili usunąć okropny obraz uwiedzionej przez niego Matrioszy, który mu się zwiduje $\mathrm{w}$ głowie, jego wola bowiem jest żelazna i w pełni nad nią panuje. Rzecz w tym - uściśla po chwili - że „nigdy nie pragnął tego uczynić, nie pragnie i nigdy pragnąć nie będzie. I trwać to będzie tak długo, dopóki nie zwariuje" (B, 648). Tak jak Stawrogin nie ma najmniejszego zamiaru być „kimś”, tak nie chce końca swojego cierpienia. Bezwzględnie afirmuje swoje bycie innym od „wszystkich”. Jego uczeń Kiriłłow sformułuje w pewnym momencie kanoniczną dla najefektowniejszych bohaterów Dostojewskiego skargę wyalienowanego apostaty, która równie dobrze mogłaby wyjść z ust samego Stawrogina: „Nie wiem, jak inni, ale ja czuję, że nie mogę tak jak wszyscy" $(B, 110)$.

\section{7.}

Wbrew optymistycznemu tembrowi interpretacji religijnych w Dostojewskim wcale niekoniecznie trzeba widzieć kogoś, kto życzył sobie triumfu niezachwianej wiary i spokoju ducha nad otchłaniami grozy i szaleństwa ludzkiego życia. I bywają rosyjscy krytycy, którzy są tego doskonale świadomi. Pisze na przykład o Dostojewskim Jewgienij Sołowiew:

Czuły i kochający - potrafił rozróżniać wokół siebie jedną złość; namiętnie przywiązany do życia, niecierpliwie odpychał je od siebie i uciekał w 'podziemie', żeby stamtąd przeklinać byt. Zimne przerażenie i zimna rozpacz raz po raz opanowywały go. Chciał żyć, jak człowiek radosny, silny, zdrowy, z miłością w sercu, ale takie życie nie było mu dane, i odtrącił od siebie rozkosz, przeklął szczęście ${ }^{34}$.

34 Е. Соловев, Достоевский. Его жизнь и литературная деятельность, <http://www. azlib.ru/s/solowxewandreewich_e_a/text_0080.shtml>, dostęp: 12.01.2015. 
Autorem jeszcze odważniejszego twierdzenia jest Jurij Ajchenwald:

pewnego razu, objęty przez litość i doświadczywszy cierpienia, [Dostojewski] pokochał je okrutną miłością, nie mógł się bez niego obejść. Jeżeli zniknęłoby z jego świata wewnętrznego i świata zewnętrznego, byłby jeszcze nieszczęśliwszy, niż był, i nie wiedziałby, co robić ze sobą, o czym pisać. To z pewnością gest daleki od łagodności; w tym jest pycha i zło ${ }^{35}$.

Ajchenwald wskazał też na związek, jaki zachodzi u Dostojewskiego między rozdzierającym poczuciem egzystencjalnego „niespełnienia” a miarą autentyczności ludzkiej egzystencji: „Nasz świat nie jest światem, w którym można by żyć szczęśliwie. O tyle, o ile człowiek jest zdrowy, o tyle, dla Dostojewskiego, nie ma kontaktu z życiem ducha (непричастен к событиял духа): tylko człowiek chory, opętany, godny jest miana człowieka"36. Dałoby się znaleźć jeszcze wiele podobnych głosów.

Być może to namiętność do wolności, ale pojętej jako prawo do cierpienia, niespełnienia i własnej zguby, sprawia, że ilekroć Dostojewski stara się pokazać nam „piękno życia”, przyjemnego, a wręcz rozkosznego, bo zgodnego z chrześcijańskim światopoglądem - a czyni to choćby ustami Makara Dołgorukiego w Młodziku, Marii Kuternóżki w Biesach, Aloszy i starca Zosimy w Braciach Karamazow, tam brzmi najmniej przekonująco, jak gdyby coś w nim samym buntowało się przed wizją proklamowanej pełni, szczęścia i owej... granicy ludzkich ambicji, jaką stanowi życie zgodne z jakimś normatywnym kodem. Szestow pisał:

nie zawsze, wręcz bardzo rzadko, ból ostrzega przed grożącym człowiekowi niebezpieczeństwem, a przyjemność zapewnia bezpieczeństwo. Odwrotnie: tym, co najbardziej niebezpieczne, co grozi żywej istocie ostateczną zgubą - zarówno duszy, jaki ciału - jest przyjemność. [...] Przyjemność dla ogromnej większości ludzi pozostaje snem, inaczej mówiąc, śmiercią duszy, jej powrotem do niebytu. Ból, cierpienie to początek przebudzenia. Przyjemne, jednostajne, zrównoważone istnienie zabija w człowieku wszystko, co ludzkie, sprowadza jego życie do roślinnej wegetacji, zawraca w łono tej nicości, z której w tak tajemniczy sposób wyciągnęła go jakaś tajemnicza siła. (Sz, 164)

To z powodu tej pasji dla wolności, wolności do wiecznego poszukiwania, którego nigdy nie nasyci odnalezienie, Dostojewski z takim zainteresowaniem i zrozumieniem pochylił się nad swoimi największymi życiowymi wykolejeńcami i to za nią pokochał swojego Stawrogina, nie będąc w stanie go ostatecznie potępić. „Na świecie nic się nie kończy” - enigmatycznie twierdzi Stawrogin w rozmowie z Barbarą Pietrowną

35 Ю.И. Айхенвальд, Достоевский, [w:] tеgоż, Силуэты русских писателей, t. 1, Москва 1998, <http://az.lib.ru/a/ajhenwalxd_j_i/text_0123.shtml>, dostęp: 12.01.2015.

36 Tamże. 
(B, 267). On nie może nie odrzucić Boga, bo Bóg stanowi ostateczny symbol końca ludzkich dążeń i zmagań, symbol pełni, oczywistości i wszystkości - ideałów, którym prawdziwy Dostojewski nigdy nie ufał, które zawsze starał się podważyć... ${ }^{37}$. Bliski zrozumienia tego był Mereżkowski, lecz owo wzbranianie się Stawrogina przez Bogiem musiał oczywiście pryncypialnie potępić:

Oto główny błąd, z którego powodu on ginie: nie na świecie w ogóle, a tylko w nim, w jego świadomości rzeczywiście 'nic się nie kończy'. Koniec wszystkiego w świadomości ludzkiej jest Bogiem; ale świadomość Stawrogina nie chce swojego końca, nie chce Boga. (M, 382)

Czy brak działania i „nieefektywność” Stawrogina świadczy o „rozpadzie” jego osobowości, jak chce wielu rosyjskich interpretatorów, a w ślad za nimi Ryszard Przybylski, czy właśnie o jego absolutnym nieprzejednaniu w chronieniu swojej osobowości? Rację przyznajemy Michaiłowi Blumenkrantzowi: „Dla Stawrogina bycie wolnym oznacza właśnie to: wolność dla samej wolności. To nie negacja tożsamości, lecz przeciwnie totalne jej utwierdzenie" 38 .

Bierdiajew, któremu często zdarza się przeczyć samemu sobie, bez satysfakcji konstatuje w Rosyjskiej idei, że u Dostojewskiego „między wolnością i szczęściem istnieje sprzeczność” 39 . W tym samym tekście (Откровение о человеке в творчестве Достоевского), w którym gigantyczne postaci Swidrygajłowa, Stawrogina i Smierdiakowa filozof określa mianem „słomianych chochołów”, „żyjących złudnym życiem” i wiodących "wampiryczną egzystencję", natrafiamy na inne słowa, podszyte wyczuwalną trwogą: „człowiek strasznie jest podniesiony u Dostojewskiego w randze, wydźwignięty na niebywałą wysokość" 40 . Czy nawet... wyżej od Boga? Dobre pytanie. W pracy pt. Historia rosyjskiej metafizyki Igor Jewłampiew argumentuje, że pod maską Absolutu, tak namiętnie poszukiwanego przez Dostojewskiego, może kryć się zarówno Bóg, jak i człowiek...41. Słynny „bunt” Iwana Karamazowa dowodzi, że w imię ludzkiego losu, zwłaszcza zaś losu tych niezasłużenie cierpiących, jak dzieci, Dostojewski gotów był odrzucić świat stworzony przez Boga. Być może wraz ze

${ }^{37}$ Por. L. Shestov, Athens and Jerusalem, ed. and transl. B. Martin, Ohio 1966, s. 355,375 .

38 M. Blumenkrantz, From Nimrod to the Grand Inquisitor: The Problem of the Demonization of Freedom in the Work of Dostoevskij, „Studies in East European Thought” 1996, vol. 48, $\mathrm{nr}$ 2/4, s. 241.

${ }^{39}$ N.A. Bierdiajew, Rosyjska idea, przeł. J.C - S.W, wyd. II popr., Warszawa 1999, s. 189.

40 Н.А. Бердяев, Откровение о человеке в творчестве Достоевского...

${ }^{41}$ Zob. И.И. Евлампиев, История русской метафизики в ХIX-XX веках. Русская философбия в поисках абсолюта, t. 1, Санкт-Петербург 2000, s. 171. 
Stawroginem pisarz ostatecznie zrozumiał, że można odrzucić świat Boży również wtedy, gdy ceną „szczęścia i harmonii” okazuje się rezygnacja $\mathrm{z}$ wolności jednostki do cierpienia i samozatraty. Mylił się w takim razie Ryszard Przybylski, próbujący za wszelką cenę widzieć w Dostojewskim pisarza o niezachwianych poglądach i wierze w odkupieńczą siłę prawosławnej miłości i pokory, gdy twierdził, że odrzucając wiarę w Boga, Stawrogin wybrał śmierć. Słuszność leży raczej po stronie bezkompromisowego Szestowa, według którego jakaś część Dostojewskiego gotowa był przyznać, że życie zaczyna się dopiero po zrezygnowaniu z „życia”, jeśli jest ono życiem „dziecka"42, pełnym niezachwianej wiary, poczucia bezpieczeństwa, oczywistości i błogiego zadowolenia: „może jest tak, iż to, co wydaje się życiem, jest śmiercią, to zaś, co wydaje się śmiercią, jest życiem...”? (Sz, 38). Dla Stawrogina „śmiercią” jest „życie”, jakie proponuje mu ojciec Tichon. Jego reakcja na ofertę starca nie może już teraz dziwić:

chce ojciec, abym ustatkował się, być może nawet ożenił się i zakończył życie jako członek tutejszego klubu, w każde święto przychodzący do monasteru. Też mi epitymia! [...] Czerwieniłem się ze wstydu na samą myśl o takiej nikczemności. $(\mathrm{B}, 656,657)$

Stawrogin niczym nie gardzi bardziej niż możliwością końca swojej męki w oazie spokoju i duchowego skupienia. Czy w tym jest pycha i zło? Czy wolność cierpienia i niespełnienia aż do autodestrukcji jest grzechem, czy może świadectwem głębi „ontologicznej realności ludzkiego ducha” - jak to określił Siemion Frank - przy której „blakną wszystkie, nawet najbardziej idealne mierniki dobra, prawdy i rozumu" 43 ?

\section{8.}

„Któż z nas uczciwie wie teraz, czym jest dobro, a czym zło!” (кmо из нас по совести знает теперь, что зло и что добро!) - napisał Dostojewski w Ogłoszeniu o prenumeracie wydawanego razem z bratem Mi-

42 Zob. na ten temat rozmowę Marii Janion, Stefana Chwina, Ewy Graczyk i innych w pracy Dzieci z serii „Transgresje”. Jej tytuł: Dlaczego Kain nie chce „stać się dzieckiem” nawiązuje do kapitalnej wypowiedzi S. Chwina, który zbliżał się nieco do proponowanej przez nas interpretacji Stawrogina, twierdząc, że: „Zbuntowany ‘fałszywy Chrystus' pozostanie buntownikiem. Przepaść jest zupełna. Nie będzie żadnego pokajania. Tajemnica Stawrogina zawiera się w tym, dlaczego Kain nie chce 'stać się dzieckiem"' - Dzieci, t. II, wybór, opracowanie i redakcja M. Janion, S. Chwin, Gdańsk 1988, s 104.

43 С.Л. Франк, Достоевский и кризис гуманизма (К 50-летию дня смерти Достоевского), [w:] О Достоевском: Творчество Достоевского в русской мысли 1881-1931, Книга, Москва 1990, s. 397. 
chaiłem czasopisma „Epoka” w 1865 roku44. Trochę dziwne to słowa, jak na „proroka prawdziwego chrześcijaństwa” (W. Sołowjow). Bardziej zresztą krzyk niż słowa. „Wydaje się - pisze Mereżkowski - że ten „krzyk samego Dostojewskiego wraz ze wszystkimi jego bohaterami jest krzykiem przerażenia przed ostateczną wolnością" (M, 296). Wolnością, która dla większości ludzi jest najstraszniejszym ciężarem, dlatego gotowi są giąć się $\mathrm{w}$ niewolniczym pokłonie przed jakimkolwiek autorytetem czy ideałem, gotowi są dążyć do tego, co „wszyscy” i pracowicie zabiegać o dobrobyt, zadowolenie i „spokój ducha”, byleby tylko nie musieć „samemu rozstrzygać, co jest dobre, a co złe" - jak mówił Dostojewski skryty pod maską Wielkiego Inkwizytora ${ }^{45}$. Byleby tylko nie wiedzieć, czym jest czas, wlekący się tak niemiłosiernie, niedający nic, poza perspektywą niekończącego się roztrząsania tragedii bycia człowiekiem... Taka była stawka Dostojewskiego! Dla tej stawki niektórzy nie tylko odrzucą nie tylko piękny, „Boży świat”, który Dostojewski tyle razy opiewał ustami swoich cnotliwych dusz, lecz także (a może przede wszystkim) - samego Boga. To jest ta otchłań, którą rosyjski pisarz odkrył wraz ze Stawroginem po drugiej stronie „granicy” i na krawędzi której zachwiał się wraz ze swoim bohaterem. Dalej nie śmiał za nim pójść, być może dlatego, że tam czaiło się już tylko jego własne szaleństwo, które od dawna szeptało doń o tym, że „wszystko się zaczyna, ale nic nie kończy”, że „niekiedy człowiek bardziej lubi cierpienie aniżeli szczęśliwość”, że „dwa razy dwa jest cztery to zasada śmierci”. Że człowiek nigdy nie będzie szczęśliwy, a Bóg w niczym mu nie pomoże, bo jest największym zagrożeniem dla ludzkiej wolności.

W tej otchłani na pewno nie rozbrzmiewała „wszystko zwyciężająca Hosanna” - jak wyobrażał sobie Gieorgij Florowski. Tu brzmiał „krzyk przerażenia". Dostojewski musiał zabić wielkiego Stawrogina, żeby ten krzyk zagłuszyć.

44 Ф.М. Достоевский, Об издании нового ежемесячного журнала „Эпоха”, литературного и политического, под редакиией Михаила Достоевского, [w:] tegoż, Полное собрание сочинений в 30 толах, Т. 20, Ленинград 1972-1990, s. 213.

45 F. Dostojewski, Bracia Karamazow, t. 1, przeł. A. Wat, przekład przejrzał i poprawił Z. Podgórzec, London 1993, s. 288. Jak zauważa Mereżkowski: „czasami za maską Wielkiego Inkwizytora skrywa się twarz samego Dostojewskiego i maska ta nagle staje się twarzą, twarz - maską; one zlewają się, mieszają i śmieją się do takiego stopnia, że w końcu nie da się odróżnić jednej od drugiej. Dostojewski niewystarczająco oddziela siebie od Wielkiego Inkwizytora: czasem jest obok niego, nawet przeciwko niemu, a czasem w nim; ale ani w jednym, ani w innym przypadku nie wie on do końca, albo nie chce wiedzieć, gdzie on jest naprawdę, jak gdyby nie tylko przed innymi, lecz także przed sobą chowałby się pod ta maską" - M, 407. 
Niczym Szatan w rajskim ogrodzie, bohater opowiadania pt. Sen śmiesznego człowieka (jeden z ostatnich opublikowanych przez Dostojewskiego tekstów, rok 1877, po nim ukazywać się będą już tylko Bracia Karamazow i Dziennik pisarza) pokazuje niewinnym i czystym ludziom ze „słonecznej planety” zło, którego dotychczas nie znali. Żyli jak dzieci błogo i szczęśliwie. Po perfidnej interwencji „cudaka” ludzie ci „nauczyli się kłamać, pokochali kłamstwo i poznali jego urok”, „przypadło im ono do gustu”. „Niezwłocznie zrodziła się lubieżność, która z kolei wydała na świat zazdrość, a zazdrość dała początek okrucieństwu”. Gdy poznali boleść i utrapienie, „pokochali je”, zaczęli wręcz „pragnąć” cierpienia. Poznawszy walkę, konflikt oraz stan niespełnienia, ludzie ze słonecznej planety nie chcieli już powrotu do swojego „raju” zadowolenia i harmonii: „nie chcieli już nawet wierzyć temu, że byli kiedyś niewinni i szczęśliwi”.

Dostojewski pragnął takiego szczęśliwego życia ludzi-dzieci z planety słońca. Ale wiedział też, że szczęście jest przywilejem miernot i niewolników.

\section{LITERATURA}

Айхенвальд Ю.И., Достоевский, [w:] tegoż, Силуэтьь русских писателей, t. 1, Москва 1998, <http://az.lib.ru/a/ajhenwalxd_j_i/text_0123.shtml>, dostęp: 12.01. 2015.

Baudelaire Ch., Lettre à Jules Janin, [w:] tegoż, Oeuvres posthumes, Nouvelle édition augmentée, Paris 2014.

Бердяев Н.А., Откровение о человеке в творчестве Достоевского, „Русская Мысль” 1918, Кн. III-IV, <http://www.vehi.net/berdyaev/otkrov.html\#_ftnref2>, dostęp: 12.01.2015.

Бердяев Н.А., Ставрогин, „Русская мысль” 1914, nr V.

Bierdiajew N., Rosyjska idea, Warszawa 1999.

Blumenkrantz M., From Nimrod to the Grand Inquisitor: The Problem of the Demonization of Freedom in the Work of Dostoevskij, "Studies in East European Thought" 1996, vol. 48, no. 2/4.

Булгаков С.Н., Русская трагедия, „Русская Мысль” 1914, Кн. IV; <http://www. vehi.net/bulgakov/tragediya.html>, dostęp: 12.01.2015.

Dostojewski F., Biesy, London 1992.

Dostojewski F., Bracia Karamazow, t. 1, London 1993.

Dostojewski F., Listy, Warszawa 1979.

Dostojewski F., Notatki z podziemia, Gracz, London 1992.

Достоевский Ф.М., Об издании нового ежемесячного журнала „Эпоха”, литературного и политического, под редакиией Михаила Достоевского, [w:] tegoż, Полное собрание сочинений в 30 томах, Т. 20, Ленинград 1972-1990. 
Dostojewski F., Zbrodnia i kara, Warszawa 2002.

Евлампиев И.И., История русской метафизики в XIX-XX веках. Русская фбилософбия в поисках абсолюта, t. 1, Санкт-Петербург 2000.

Франк С.Л., Достоевский и кризис гуманизма (К 50-летию дня смерти Достоевского), [w:] О Достоевскол: Творчество Достоевского в русской мысли 1881-1931, Москва 1990.

Флоровский Г.В., Религиозные телы Достоевского, [w:] tegoż, О Достоевскол, Москва 1990.

Гессен С.И., Трагедия зла (фбилософбский образ Ставрогина), „Путь” 1932, nr 36. <http://www.odinblago.ru/path/36/3>, dostęp: 12.01.2015.

Гроссман Л., Достоевский, Москва 1963.

Иванов В.И., Достоевский и ролан-трагедия, „Русская Мысль” 1911, май-июнь, $<\mathrm{http} / / / w w w . v e h i . n e t / d o s t o e v s k y / i v a n o v . h t m l \# \_f t n 1>$, dostęp: 12.01.2015.

Janion M., Czy Stawrogin jest postacia tragicznq?, [w:] M. Janion, R. Przybylski, Sprawa Stawrogina, Warszawa 1996.

Janion M., Chwin S., (wybór, opracowanie, redakcja), Dzieci, t. 2, Gdańsk 1988.

Jewdokimow D., Człowiek przemieniony, Fiodor M. Dostojewski wobec tradycji Kościoła Wschodniego, Poznań 2009.

Лосский Н.О., Достоевский и его христианское мировоззрение, New York 1953.

Мережковский Д., Л. Толстой и Достоевский, Москва 2000.

Nietzsche F., To rzekt Zaratustra, Warszawa 1999.

Pope R., Turner J., Toward Understanding Stavrogin, "Slavic Review” 1990, vol. 49, no. 4.

Przybylski R., Stawrogin, [w:] M. Janion, R. Przybylski, Sprawa Stawrogina, Warszawa 1996.

Соловев Е., Достоевский. Его жизнь и литературная деятельность, <http:// www.azlib.ru/s/solowxewandreewich_e_a/text_0080.shtml>, dostęp: 12.01.2015.

Sołowjow W., Trzy mowy ku czci Dostojewskiego, [w:] Okrutny talent. Dostojewski we wspomnieniach, krytyce i dokumentach, Kraków 1984.

Степун Ф.А., «Бесь» и большевистская революиия, [w:] Русское зарубежье в год тьссячелетия крещения Руси, Москва 1991, <http://www.vehi.net/dostoevsky/ stepun.html>, dostęp: 12.01.2015.

Shestov, L. Athens and Jerusalem, Ohio 1966.

Szestow L., Na szalach Hioba. Duchowe wędrówki, Warszawa 2003. 